from osteo-arthritis, were observed over a 12-year period, taking a total of 820 courses of phenylbutazone of variable duration. The maximum dose was $200 \mathrm{mg}$. The incidence of side-effects was 10 per cent., 0.5 per cent. being of a serious nature. All serious complications occurred in the gastro-intestinal tract. Side-effects were more frequent in females, the sex incidence ratio being 1:3. A survey of the literature reveals the incidence of side-effects to be 46 per cent. at a dose level of $600 \mathrm{mg}$. daily, and 24 per cent. at $400 \mathrm{mg}$. daily, serious sideeffects occurring in 2 per cent. of cases on a dose of 600 mg. daily.

Periarteritis Nodosa in P.N. Mice. R. D. WIGLEY, K. G. Couchman, and R. Maule (Palmerston North): Periarteritis nodosa, closely resembling the human disease described by Kussmaul and Maier (1866), was found in 60 per cent. of 319 P.N. mice over one year old. Antinuclear factor showed a significant association with arteritis. Red cell antibodies in 10 per cent. of the mice were not clearly associated with anaemia. The arteritis was not associated with intercurrent amyloid, chronic virus pneumonia or lymphoma. Eight of 100 mice had thymic germinal centres and six of the eight had arteritis. Fifteen of 297 mice of other inbred strains showed arteritis and fifteen of 284 NZB/B1 mice. NZB F1 hybrids showed a higher incidence of glomerulitis than arteritis which reached a peak incidence of 50 per cent. in BXY hybrids.

Vitamin $\mathbf{B}_{12}$ Absorption in Rheumatoid Arthritis. K. G. Couchman, L. Beider, and R. A. D. Wigley (Palmerston North): Vitamin B 12 absorption was investigated by the Schilling test on 69 patients with definite or classical rheumatoid arthritis and matched controls. The control results fitted a logarithmic normal distribution with a mean of 25.7 per cent. and a two-standard deviation range of $11-62$ per cent. A regression with age was seen, giving a mean of 30 per cent. at age 30 , declining to 20 per cent. at 90 years. This regression was much more marked in the rheumatoid patients, the mean absorption at 85 years being 10 per cent. Nineteen rheumatoid cases absorbed less than 11 per cent. and seven of these less than 7 per cent., whereas only two control cases absorbed less than 11 per cent. Gastric antibodies were found in six of seventeen rheumatoid patients and in only one of 26 controls, while only four of ten rheumatoid cases exhibited both low $\mathrm{B}_{12}$ absorption (below 11 per cent.) and gastric antibody. Any effect of drug treatment is under further investigation. There was a significant relationship between a Schilling test below 6 per cent. and a low haemoglobin, but there were insufficient numbers to demonstrate an association with low serum $B_{12}$ levels.

\title{
OBITUARY ALESSANDRO ROBECCHI, 1906-67
}

Professor Alessandro Robecchi died suddenly on December 21, 1967, at the early age of 61 . He was born in Turin in 1906 and qualified with distinction in 1929. After two years at Acqui, he returned to the University of Turin, working in the Institute of Tropical Medicine, 1938-1940, and then in the Department of Internal Medicine until 1950. In 1952 he was appointed Director of the Rheumatology Centre of the University.

From 1959-1961 he was President of the European League against Rheumatism and in 1965 became President of the International League against Rheumatism, an office he would have surrendered after the meeting at Prague in 1969. He was largely responsible for organizing the very successful international meeting at Rome in 1963.

He contributed much to the literature of his specialty, including papers on radiology of joints, classification and terminology, psoriatic arthritis, and disk degeneration.

Although all rheumatologists will mourn the passing of an international leader in this subject, many will feel even more the loss of a real friend. He was always happy and serene, yet at the same time conscientious and a born organizer. His vocation and office took him to every part of the

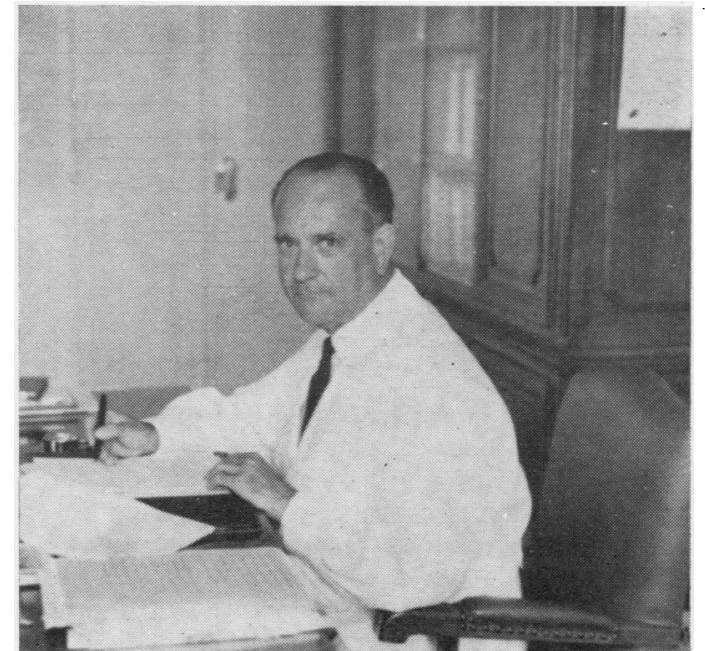

world and wherever that might be he was always helpful and courteous but never pushing or interfering. He was a great family man, often taking his wife or daughter with him to conferences. Our sympathy goes out to them in their very great loss.

G.D.K. 